University of Nebraska - Lincoln

DigitalCommons@University of Nebraska - Lincoln

$1-6-2007$

\title{
Satellite-derived estimates of potential carbon sequestration through afforestation of agricultural lands in the United States
}

\author{
Christopher Potter \\ NASA Ames Research Center, chris.potter@nasa.gov \\ Steven Klooster \\ California State University Monterey Bay \\ Seth Hiatt \\ San Jose State University \\ Matthew Fladeland \\ NASA Ames Research Center \\ Vanessa Genovese \\ California State University Monterey Bay
}

See next page for additional authors

Follow this and additional works at: https://digitalcommons.unl.edu/nasapub

Part of the Physical Sciences and Mathematics Commons

Potter, Christopher; Klooster, Steven; Hiatt, Seth; Fladeland, Matthew; Genovese, Vanessa; and Gross, Peggy, "Satellite-derived estimates of potential carbon sequestration through afforestation of agricultural lands in the United States" (2007). NASA Publications. 21.

https://digitalcommons.unl.edu/nasapub/21

This Article is brought to you for free and open access by the National Aeronautics and Space Administration at DigitalCommons@University of Nebraska - Lincoln. It has been accepted for inclusion in NASA Publications by an authorized administrator of DigitalCommons@University of Nebraska - Lincoln. 


\section{Authors}

Christopher Potter, Steven Klooster, Seth Hiatt, Matthew Fladeland, Vanessa Genovese, and Peggy Gross 


\title{
Satellite-derived estimates of potential carbon sequestration through afforestation of agricultural lands in the United States
}

\author{
Christopher Potter · Steven Klooster • Seth Hiatt • \\ Matthew Fladeland · Vanessa Genovese · Peggy Gross
}

Received: 10 October 2004 / Accepted: 3 August 2006 / Published online: 6 January 2007

(C) Springer Science + Business Media B.V. 2007

This article is a U.S. government work, and is not subject to copyright in the United States.

\begin{abstract}
Afforestation of marginal agricultural lands represents a promising option for carbon sequestration in terrestrial ecosystems. An ecosystem carbon model was used to generate new national maps of annual net primary production (NPP), one each for continuous land covers of 'forest', 'crop', and 'rangeland' over the entire U. S. continental area. Direct inputs of satellite "greenness" data from the Advanced Very High Resolution Radiometer (AVHRR) sensor into the NASA-CASA carbon model at 8-km spatial resolution were used to estimate spatial variability in monthly NPP and potential biomass accumulation rates in a uniquely detailed manner. The model predictions of regrowth forest production lead to a conservative national projection of $0.3 \mathrm{Pg} \mathrm{C}$ as potential carbon stored each year on relatively low-production crop or rangeland areas. On a regional level, the top five states for total crop afforestation potential were: Texas, Minnesota, Iowa, Illinois, and Missouri, whereas the top five states for total rangeland afforestation potential are: Texas, California, Montana, New Mexico, and Colorado. Afforestation at this level of intensity has the capacity to offset at least one-fifth of annual fossil fuel emission of carbon in the United States. These projected afforestation carbon gains also match or exceed recent estimates of the annual sink for atmospheric $\mathrm{CO}_{2}$ in currently forested area of the country.
\end{abstract}

\section{Introduction}

Carbon sequestration in terrestrial ecosystems refers to the process of increasing atmospheric carbon dioxide $\left(\mathrm{CO}_{2}\right)$ storage in standing biomass and soils on a semi-permanent basis. Previous estimates of the potential for global biospheric carbon sequestration commonly

C. Potter $(\bowtie) \cdot$ M. Fladeland

NASA Ames Research Center, Moffett Field, CA

e-mail: cpotter@mail.arc.nasa.gov

S. Klooster · V. Genovese

California State University Monterey Bay, Seaside, CA

S. Hiatt

San Jose State University and Education Associates, Moffett Field, CA 
fall within a range of 1-2 Pg per year (IPCC 2000). Opportunities for land use conversion, afforestation, and enhanced agroforestry management could become parts of national carbon sequestration strategies aimed at "buying time" to allow other, more permanent technological options for long-term $\mathrm{CO}_{2}$ sequestration to be implemented (Marland et al. 2001). Biomass from afforested lands can be harvested periodically as renewable fuel for energy production and reduction of fossil fuel sources of greenhouse gases in the atmosphere (Graham 2003).

Generalized global ranges for afforestation rates of carbon sequestration (above and below ground) range in temperate and tropical regions from 1.5 to $4.5 \mathrm{t} \mathrm{Cha}^{-1} \mathrm{yr}^{-1}$ (Dixon 1995). There are, however, few detailed nationwide analyses for the United States of the potential for carbon sequestration resulting from afforestation of crop and rangeland areas. Turner et al. (1995) reviewed the status of carbon sequestration activities in the U.S. forestry sector, including increasing the area and productivity of forest lands, agroforestry, and use of harvested materials in durable wood products. An inventory of carbon sink components for the country was developed by Pacala et al. (2001), who reported from U.S. Department of Agriculture inventories that $0.15 \mathrm{Pg} \mathrm{C}$ per yr was sequestered on commercial and non-commerical forest lands in the coterminous U.S. over the past 20 years. Carbon gains from new afforestation and reforestation activities were not differentiated in this analysis from combined forest inventory records of gains and losses. Nonetheless, because natural (unmanaged) forests are generally more vulnerable than planted forests to interannual variation in climate and disturbance impacts on carbon sink fluxes, managed afforestation practices can be productive additions to help offset industrial $\mathrm{CO}_{2}$ emissions over the next few decades.

Projections of afforestation carbon gains from other individual case studies have been documented in recent years (Plantinga et al. 1999; EIA 2004; Pew Center 2004). Many of these case studies describe the planting of trees on marginal farmland and pasture or rangelands. Extrapolation of these few examples to the entire United States is not realistic however, due to variability in forest growth conditions across diverse climate, soil, hydrologic, and elevation zones.

In this study, a new combination of ecosystem carbon modeling and high-resolution land cover mapping of the North American continent by the MODIS (Moderate Resolution Imaging Spectroradiometer) satellite sensor was used to estimate potential carbon sequestration rates in United States croplands and rangelands resulting from projected afforestation activities. The main question addressed was "How much atmospheric $\mathrm{CO}_{2}$ could be sequestered over the next $20-30$ years if a moderate percentage (25\% or less) of United States croplands and rangelands were afforested with native tree species?" The high level of spatial detail produced from this remote sensing analysis makes the methods presented unique and permits state-level (and, for the first time, possibly finer) assessments of the areas best suited to crop and rangeland afforestation efforts.

\section{Study approach}

Afforestation carbon gains on agricultural lands of the United States can be assessed on a "wall-to-wall" basis using ecosystem modeling and regional remote sensing data sets. To do this, it is necessary to run our nationwide ecosystem model for both baseline (current) agricultural and (projected) afforested scenarios, and in the process, extend satellite observations of vegetation properties from forested areas across ecoregions where tree cover is currently sparse.

The NASA-CASA model (Potter et al. 1999, 2003) was used to generate three different national maps of annual net primary production (NPP), one each for continuous land covers of 'forest', 'crop', and 'rangeland' over the entire U.S. continental area. Direct inputs of 
satellite "greenness" data from the Advanced Very High Resolution Radiometer (AVHRR) sensor into the NASA-CASA model at 8-km spatial resolution were used to estimate spatial variability in monthly NPP and potential biomass accumulation rates. Monthly NPP flux of atmospheric $\mathrm{CO}_{2}$ is predicted using the relationship between greenness reflectance properties and the fraction of absorption of photosynthetically active radiation (FPAR), modified by time-varying surface solar irradiance, $S_{\mathrm{r}}$, and stress scalar terms for temperature $(T)$ and moisture $(W)$ effects (Equation 1).

$$
\mathrm{NPP}=S_{\mathrm{r}} \mathrm{FPAR} e_{\max } T W
$$

The light utilization efficiency term, $e_{\max }$, is set uniformly at $0.39 \mathrm{~g} \mathrm{C} \mathrm{MJ}^{-1} \mathrm{PAR}$, a value that derives from calibration of predicted annual NPP to previous field estimates (Potter et al. 1993). This model calibration has been validated globally by comparing predicted annual NPP to more than 1900 field measurements of NPP (Potter et al. 2003).

Nationwide NPP flux for each of three different land cover classes (forest, crop, and rangeland or pasture land) was computed separately by the model at 8-km spatial resolution using interpolated (by inverse distance weighting) monthly AVHRR FPAR input files for the late 1990s (Knyazikhin et al. 1998). The first step in this process was to aggregate the MODIS 1-km land cover map (Friedl et al. 2002) to 8-km pixel resolution to determine the predominant land cover class in each pixel as either forest, crop, rangeland, or other classes such as water or urban. To generate spatially continuous model inputs to NASA-CASA for monthly forest FPAR, 8-km FPAR values exclusively from nearby MODIS forest land cover pixels were used in the spatial interpolation computations for pixels that were not predominantly forest cover. The interpolated monthly FPAR inputs for spatially continuous crop and rangeland simulations were likewise generated using nearby 8-km FPAR values exclusively from MODIS crop and rangeland cover pixels for pixels that were not predominantly crop and rangeland cover, respectively.

The NASA-CASA computation for monthly NPP (Equation 1) was made at 8-km resolution using each of the three interpolated FPAR time series to produce continuous nationwide production covers of forest, crop, and rangeland (or pasture land). In all three NPP runs, the same mean climate (monthly temperature, precipitation, and solar radiation flux; VEMAP 2000) drivers were used. Although effects of irrigation or any other supplemental water management were not included directly in these NASA-CASA model runs for forest and rangeland simulations, the interpolated satellite FPAR data on which crop NPP results were based may reflect irrigated growing conditions in regions of the country where this practice is common.

The CASA moisture stress term $(W)$ applied in current rangeland areas that use an extended forest FPAR will still impose severe limitations on any predicted value of afforestation NPP. The climate inputs used for the two model runs (afforested versus non-forest) were all identical. This means that the simulated tree growth on moisture-limited rangeland areas of the U. S. will be strongly constrained by low soil water availability in the same manner as rangeland vegetation is constrained by moisture-limitations. CASA model predictions for afforestation NPP are influenced mainly by the change in settings to a deeper rooting depth for planted trees $(2 \mathrm{~m})$ compared for crops $(1 \mathrm{~m})$, which would alleviate a minor portion of simulated water stress in semi-arid rangeland areas.

Furthermore, it is important to note that cropland FPAR can be higher than nearby forest FPAR throughout much of the North American growing season. Consequently, the assignment of monthly FPAR values from forest areas to nearby non-forest areas does not necessarily result in higher productivity estimates for the afforestation simulations compared to the 
present coverage of crop and rangeland NPP from CASA estimates using actual MODIS data.

The 1-km MODIS land cover map was next used to create a new U. S. continental mask file that assigned $1=$ 'crop' and $2=$ 'rangeland' land cover classes, and $3=$ 'forest' classes. For all $1-\mathrm{km}$ pixels assigned a value $=1$ in the new mask, we generated a $1-\mathrm{km}$ annual crop NPP map by assigning the corresponding $\mathrm{C}$ flux values from the continuous 8-km 'crop' annual NPP outputs from NASA-CASA. For all $1-\mathrm{km}$ pixels assigned a value $=2$ in the new mask, we generated a annual 1-km rangeland NPP map by assigning the corresponding C flux values from the continuous 8-km 'rangeland' annual NPP outputs from NASA-CASA. The resulting NPP values represented a $1-\mathrm{km}$ resolution baseline NPP map for crop and rangeland land covers.

To estimate potential afforestation changes in carbon pools, we used the continuous 8-km forest annual NPP values from NASA-CASA at these same 1-km pixels (mask values $=1$ or 2) to generate two alternative annual 1-km NPP maps for afforested crop or rangeland areas, respectively. Wherever the forest annual NPP value was greater than the crop annual NPP value, we assigned $100 \%$ of the forest NPP value, otherwise we retained the baseline crop annual NPP value and assumed that no afforestation increment for carbon gain could be projected. The same NPP assignment procedure was applied using the baseline rangeland' NPP values for comparison to the forest NPP values. This approach was applied under the assumption that sufficient economic incentives to plant new trees would not be present at 1$\mathrm{km}$ locations where the corresponding crop or the rangeland annual baseline NPP value was higher than the potential forest NPP value. Conversely, relatively low-production croplands and rangelands where potential forest NPP was determined to be higher on an annual basis would constitute the prime areas of the country with the highest incentives for improving carbon sequestration potentials by tree planting.

\section{Case study evaluations with adjustments for carbon loss}

To evaluate NASA-CASA model estimates of afforestation carbon gains over time, several case study sequestration projects (EIA 2004) were documented for comparison to the model predictions (Table 1). We initially delineated the general geographic area where a reported carbon sequestration project had been established. This geographic delineation was commonly in reference to a reported city, county, or management unit location(s). Within this general project area, we estimated potential afforestation carbon gains beginning from NASA-CASA model NPP predictions, which are expressed at $1-\mathrm{km}$ spatial resolution in average flux units of $\mathrm{g} \mathrm{C} \mathrm{m}^{-2} \mathrm{yr}^{-1}$. A sub-area of $8 \times 8 \mathrm{~km}$ (=64 1-km MODIS pixels) was selected to represent the general geographic area. The lowest productivity cropland NPP was identified as a baseline for potential carbon gain and compared to the NASA-CASA model estimate for annual forest NPP derived from interpolated satellite image products that cover the same $8 \times 8 \mathrm{~km}$ project sub-area. Carbon sequestered over the projected years of afforestation was computed as the highest interpolated forest NPP value in the 64 pixel sub-area, adjusted for the total area of the reported sequestration project. Predicted wood biomass from the NASA-CASA model for a nearby group of currently forested pixels was identified as an additional check on the potential carbon sequestration reported for each afforestation project.

To standardize the NASA-CASA model afforestation estimates of carbon gain against the projected carbon sequestration total over each case study area, it was necessary to infer the probable combined effects of dead biomass decomposition, forest disturbance, and aging (abbreviated DDA for decomposition, disturbance, and aging) on net carbon sequestration rates for the projected length of the case study. In any forestation project, carbon 


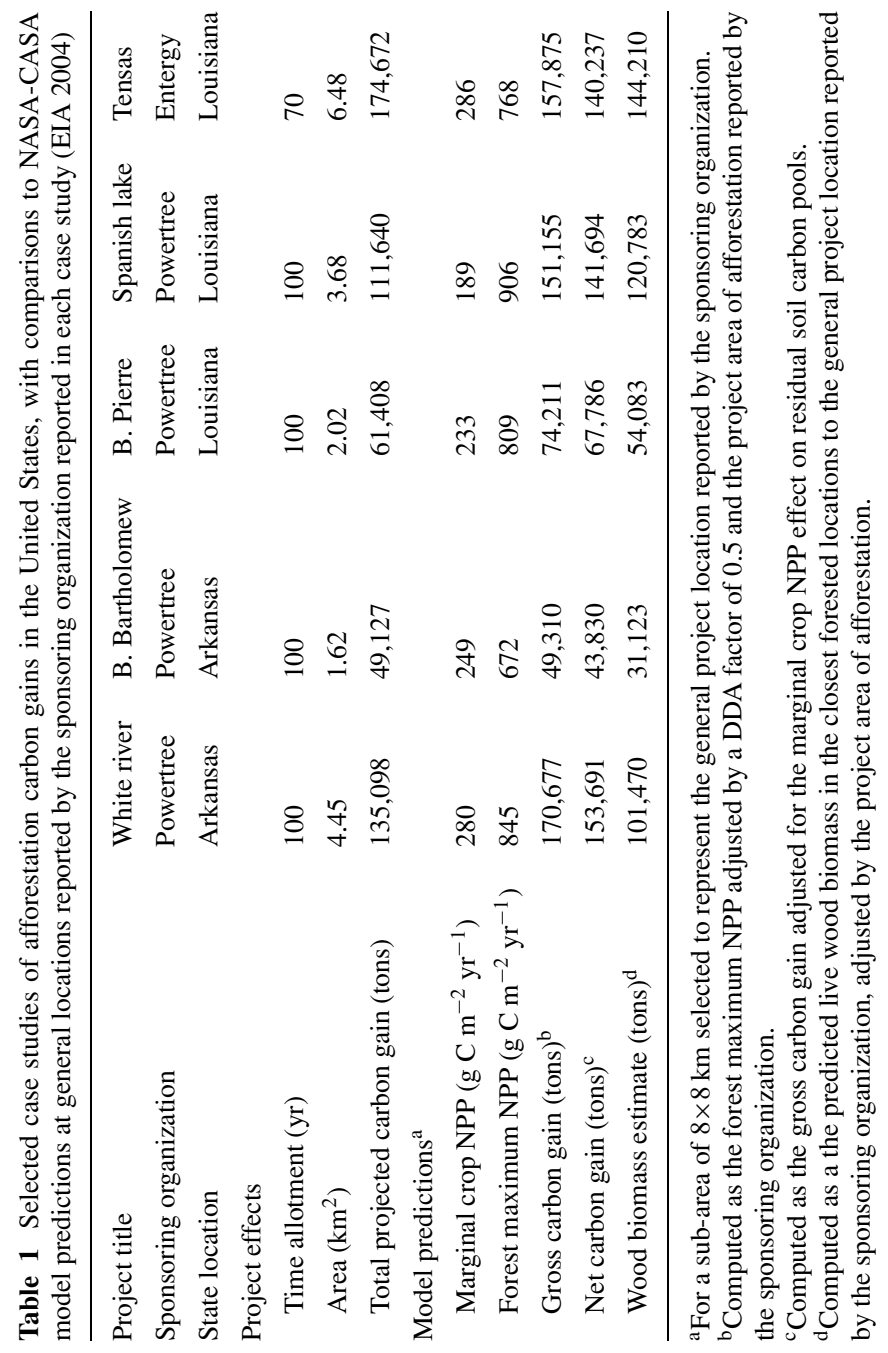


sequestration potential in vegetation and soils may decline over a time period on the order of several decades to centuries, depending upon the forest type, species selection, soil nutrient availability, elevation, and latitudinal zone (Brown et al. 1996). While up to $80 \%$ of annual net aboveground production may be allocated to wood production in trees devoted to plantation forestry (Ryan et al. 1996), a lower fraction of annual NPP will be sequestered over decades of forest growth at the landscape or regional level, owing to the diversity of tree growing conditions over large scales and an increased probability of a damaging disturbance event such as fire, wind, or pest damage. Accordingly, the IPCC (2000) has adopted assumptions from the forest (re)growth model of Marland and Schlamadinger (1997), which predicts that stand carbon accumulation is linear with time until half of the maximum is achieved and then slows gradually to approach the maximum asymptotically.

To account for stand aging and mortality in afforestation projects, the United States Department of Energy Voluntary Reporting of Greenhouse Gases Program assumes a (DDA-like) "Survival Factor", defined as the fraction of trees surviving at the end of the reporting period (EIA 2003a). At 15 years of growth, the mean Survival Factor is 0.5 and at 40 years it is 0.3 . This means that less than one-third of all trees originally planted are still sequestering carbon after 50 years and that a sizable fraction of the carbon in the $>70 \%$ of originally planted trees having died has been lost to biomass decomposition.

Using a constant DDA adjustment value of 0.5 on NPP carbon gains across all case study locations (Table 1), comparison of projected afforestation carbon gains in the United States (EIA 2004) with NASA-CASA model predictions of gross carbon gain show close agreement $\left(R^{2}=0.81\right.$ for linear regression coefficient; $\left.p<0.05\right)$. NASA-CASA model predictions of carbon accumulation rates in live wood biomass for a nearby group of currently forested pixels (according to the 1-km MODIS map) also showed close agreement $\left(R^{2}=0.88 ; p<0.01\right)$ with projected carbon gains from the case studies. Inclusion of the predicted contributions of marginal crop production on carbon sequestration in surface soil pools did not improve the match of model predictions of net carbon gain to projected carbon gains from the case studies, although it is unlikely that past or future changes soil carbon pools have been adequately addressed in any of the case studies reported to date.

\section{Regional and national estimates}

National level extrapolation of our satellite-driven NASA-CASA model suggest that afforestation of either crop or rangeland could result in a maximum gross rate of sequestration of nearly $1.2 \times 10^{15} \mathrm{~g}(\mathrm{Pg})$ of carbon per year in newly forested plant production, assuming $100 \%$ area planted in trees of these non-forest ecosystems (Tables 2 and 3). Afforestation of $100 \%$ of any agricultural production area is not realistic however. If it can be assumed instead that $25 \%$ of crop or rangeland area forested is a more realistic objective, and a constant DDA adjustment value of 0.5 on annual NPP captured can be applied uniformly for long-term storage on a site in wood biomass and soil organic pools, then the total net sequestration potential nationwide could be as high as $0.3 \mathrm{Pg} \mathrm{C}$ annually for U.S. crop or rangeland areas combined. The DDA adjustment is analogous to an estimate of net ecosystem production gains of carbon in forests, which take soil decomposition and disturbance factors into account.

The mean nationwide rate for gross annual sequestration of carbon in afforested crop areas (Fig. 1) was predicted to be higher (at $534 \mathrm{~g} \mathrm{C} \mathrm{m}^{-2} \mathrm{yr}^{-1}$ ) than the mean nationwide rate for annual sequestration in afforested rangeland (at $498 \mathrm{~g} \mathrm{C} \mathrm{m}^{-2} \mathrm{yr}^{-1}$ ). Nevertheless, relatively low-production rangeland area (Fig. 2) exceeds relatively low-production crop area by 3.48 million $\mathrm{km}^{2}$ compared to 2.14 million $\mathrm{km}^{2}$ nationwide, which nearly equalizes the total annual sequestration potential between the two agricultural cover classes. 
Table 2 Potential afforestation carbon gains in relatively low-production croplands, for the first 20 states followed by all other states combined, sorted in terms of total predicted carbon sink flux per year

\begin{tabular}{|c|c|c|c|c|c|}
\hline State & Area $\left(\mathrm{km}^{2}\right)$ & $\operatorname{Min}\left(\mathrm{g} \mathrm{C} \mathrm{m}^{-2}\right)$ & $\operatorname{Max}\left(\mathrm{g} \mathrm{C} \mathrm{m}^{-2}\right)$ & Mean $\left(\mathrm{g} \mathrm{C} \mathrm{m}^{-2}\right)$ & Total (g C) \\
\hline Texas & 184717 & 0 & 820 & 481 & $8.88 \mathrm{E}+13$ \\
\hline Minnesota & 142403 & 0 & 698 & 558 & $7.94 \mathrm{E}+13$ \\
\hline Iowa & 143274 & 0 & 696 & 538 & $7.71 \mathrm{E}+13$ \\
\hline Illinois & 135869 & 0 & 769 & 535 & $7.27 \mathrm{E}+13$ \\
\hline Missouri & 113142 & 0 & 860 & 591 & $6.68 \mathrm{E}+13$ \\
\hline Wisconsin & 97060 & 0 & 706 & 595 & $5.77 \mathrm{E}+13$ \\
\hline North Dakota & 125812 & 0 & 614 & 441 & $5.55 \mathrm{E}+13$ \\
\hline Nebraska & 106015 & 0 & 637 & 446 & $4.73 \mathrm{E}+13$ \\
\hline Florida & 69920 & 0 & 1045 & 638 & $4.46 \mathrm{E}+13$ \\
\hline South Dakota & 86231 & 261 & 623 & 510 & $4.40 \mathrm{E}+13$ \\
\hline Indiana & 81954 & 0 & 749 & 526 & $4.31 \mathrm{E}+13$ \\
\hline Michigan & 74738 & 0 & 717 & 549 & $4.10 \mathrm{E}+13$ \\
\hline Ohio & 71770 & 0 & 714 & 564 & $4.05 \mathrm{E}+13$ \\
\hline Georgia & 64934 & 0 & 950 & 608 & $3.95 \mathrm{E}+13$ \\
\hline Kansas & 76727 & 0 & 803 & 461 & $3.54 \mathrm{E}+13$ \\
\hline North Carolina & 50116 & 0 & 889 & 603 & $3.02 \mathrm{E}+13$ \\
\hline Kentucky & 47586 & 0 & 772 & 598 & $2.85 \mathrm{E}+13$ \\
\hline Arkansas & 45155 & 0 & 854 & 607 & $2.74 \mathrm{E}+13$ \\
\hline Louisiana & 41408 & 0 & 923 & 637 & $2.64 \mathrm{E}+13$ \\
\hline Tennessee & 38918 & 0 & 861 & 631 & $2.45 \mathrm{E}+13$ \\
\hline Mississippi & 39563 & 0 & 922 & 619 & $2.45 \mathrm{E}+13$ \\
\hline All others & 302830 & 0 & 924 & 514 & $1.63 \mathrm{E}+14$ \\
\hline TOTAL & 2140142 & 0 & 1045 & 534 & $1.16 \mathrm{E}+15$ \\
\hline
\end{tabular}

Corrections for probable NPP loss over time due to decomposition, disturbance and aging in predicted forest stands are not included below.

On a regional level, the top five states for total crop afforestation potential were: Texas, Minnesota, Iowa, Illinois, and Missouri, whereas the top five states for total rangeland afforestation potential are: Texas, California, Montana, New Mexico, and Colorado. All of these highest statewide totals resulted principally from the extensive area coverage of crop and rangeland, rather than the highest predicted rates of annual sequestration among states on a unit area basis.

Florida and Arkansas were the two states with the highest predicted rates of annual sequestration on a unit area basis for crop and rangeland (or pasture), respectively. The next three states with the highest predicted rates of annual sequestration in crop areas, namely Georgia, Louisiana, and Mississippi, are also located in the southeastern region of the country. The only state in the western region of the country with rates of predicted annual sequestration nearly as high those in the southeastern states was Oregon for afforestation in rangelands.

While the assignment of FPAR values from forested areas to nearby nonforested areas may at initially appear misleading, we contend that this method is the most robust one available to us for simulations of production afforestation scenarios. First, all climate and soil controls over the modeled NPP at nearby nonforested locations remain as they have been reported for those (predominantly rangeland) ecosystems. These localized climate and soil factors 
Table 3 Potential afforestation carbon gains in relatively low-production rangelands, for the first 20 states followed by all other states combined, sorted in terms of total predicted carbon sink flux per year

\begin{tabular}{|c|c|c|c|c|c|}
\hline State & Area $\left(\mathrm{km}^{2}\right)$ & $\operatorname{Min}\left(\mathrm{g} \mathrm{C} \mathrm{m}^{-2}\right)$ & $\operatorname{Max}\left(\mathrm{g} \mathrm{C} \mathrm{m}^{-2}\right)$ & Mean $\left(\mathrm{g} \mathrm{C} \mathrm{m}^{-2}\right)$ & Total ( $\mathrm{g} \mathrm{C})$ \\
\hline Texas & 446119 & 0 & 816 & 348 & $1.55 \mathrm{E}+14$ \\
\hline California & 283197 & 0 & 814 & 343 & $9.70 \mathrm{E}+13$ \\
\hline Montana & 279899 & 0 & 697 & 335 & $9.38 \mathrm{E}+13$ \\
\hline New Mexico & 293095 & 0 & 722 & 271 & $7.95 \mathrm{E}+13$ \\
\hline Colorado & 210294 & 0 & 775 & 359 & $7.56 \mathrm{E}+13$ \\
\hline Nevada & 283273 & 0 & 618 & 260 & $7.38 \mathrm{E}+13$ \\
\hline Arizona & 274058 & 0 & 616 & 256 & $7.02 \mathrm{E}+13$ \\
\hline Oklahoma & 134761 & 0 & 824 & 504 & $6.79 \mathrm{E}+13$ \\
\hline Wyoming & 226554 & 147 & 705 & 298 & $6.74 \mathrm{E}+13$ \\
\hline Utah & 197660 & 0 & 700 & 319 & $6.31 \mathrm{E}+13$ \\
\hline Kansas & 133446 & 0 & 729 & 416 & $5.55 \mathrm{E}+13$ \\
\hline Idaho & 129645 & 0 & 716 & 369 & $4.79 \mathrm{E}+13$ \\
\hline Oregon & 133122 & 0 & 857 & 346 & $4.60 \mathrm{E}+13$ \\
\hline South Dakota & 106073 & 194 & 618 & 292 & $3.09 \mathrm{E}+13$ \\
\hline Nebraska & 92672 & 207 & 520 & 303 & $2.81 \mathrm{E}+13$ \\
\hline Washington & 60532 & 0 & 784 & 352 & $2.13 E+13$ \\
\hline North Dakota & 52284 & 279 & 595 & 332 & $1.74 \mathrm{E}+13$ \\
\hline Arkansas & 21929 & 0 & 783 & 658 & $1.44 \mathrm{E}+13$ \\
\hline Florida & 20320 & 0 & 985 & 557 & $1.13 \mathrm{E}+13$ \\
\hline Mississippi & 15282 & 0 & 853 & 619 & $9.46 \mathrm{E}+12$ \\
\hline Alabama & 14303 & 0 & 842 & 607 & $8.68 \mathrm{E}+12$ \\
\hline All others & 76479 & 0 & 890 & 584 & $4.71 E+13$ \\
\hline TOTAL & 3484997 & 0 & 985 & 498 & $1.18 \mathrm{E}+15$ \\
\hline
\end{tabular}

Corrections for probable NPP loss over time due to decomposition, disturbance and aging in predicted forest stands are not included below.

will strongly constrain any potential overestimates of seasonal FPAR values assigned from nearby forested areas. Secondly, the areas classified as predominantly forested in the MODIS $1-\mathrm{km}$ land cover map used in this study are frequently a near 50\%-50\% mixture of forest and nonforested cover types (Friedl et al. 2002), so that the FPAR values assigned to the nearby rangeland areas already reflect nonforest attributes of seasonal greenness.

To further qualify the model results relative to the use of remote sensing values from forested areas to predict carbon sequestration in nonforested areas, Fig. 3 shows the maximum distance from a forest FPAR value interpolated into the crop and rangeland areas of the U.S. This analysis shows that the farthest distance for the FPAR forest interpolations were in three regions of the country: the Cornbelt of Iowa, Nebraska, and North Dakota, the Panhandle of western Texas and Oklahoma, and the Great Basin of Nevada.

To qualify the model results relative to moisture requirements of planted forests, in Fig. 4, we show the ratio of CASA's predicted annual EET to PET (i.e., Estimated versus Potential Evapotranspiration). This ratio is presented as an index of where and how much water newly planted trees would require as supplemental irrigation in order to sustain a forest stand in the non-forest (predominantly western rangeland) areas. 


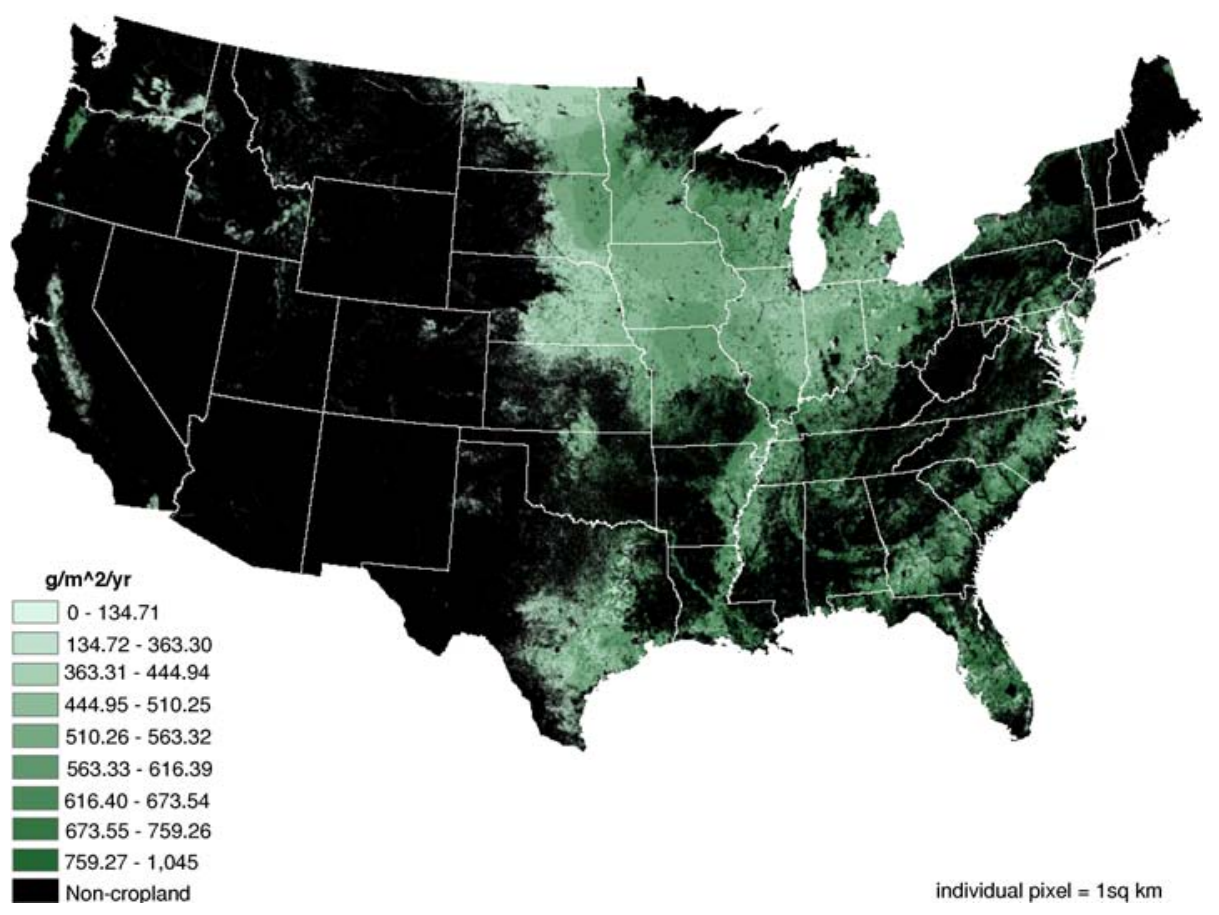

Fig. 1 Potential afforestation carbon gains in relatively low-production crop areas mapped to show predicted gross carbon sink flux per year at $1-\mathrm{km}$ resolution. Corrections for probable NPP loss over time due to decomposition, disturbance and aging in predicted forest stands are not included.

As a general rule, about $20 \%$ of aboveground forest biomass is eventually sequestered in soils, litter, and below-ground biomass (Nilsson and Schopfhauser 1995) in the absence of complete land use conversion over many decades. We expanded on this hypothesis by a comparison of non-equilibrium soil $\mathrm{C}$ accumulation estimates (over several hundred years) from the NASA-CASA model under afforested versus non-forest covers. Results for 300-yr projected carbon sinks suggest that $\mathrm{U}$. S. croplands and rangelands could together store nearly 6.1 Pg C in accumulated dead wood pools, assuming $100 \%$ area planted in trees for these nonforest ecosystems. The same CASA model results for 300-yr projected carbon accumulation in surface mineral soil pools imply that U. S. croplands could store nearly $5.3 \mathrm{Pg} \mathrm{C}$ and that U. S. rangelands could store nearly $2.1 \mathrm{Pg} \mathrm{C}$, again assuming $100 \%$ area planted in trees. The projected capacity of cropland soils to store additional carbon under afforestation scenarios far exceeds that of rangeland soils because the default CASA model settings for microbial turnover rates in perennially cultivated cropland soils are $25 \%$ faster than in rangeland soils (Potter et al. 1993). Faster microbial processing of crop residue carbon that is generally plowed into cultivated soils means lower potential storage capacity for continuously cropped soils, relative to perennially grass-covered rangeland or to tree-covered forest soils (Parton et al. 1987).

\section{Discussion}

According to the satellite-driven model predictions presented in this study, there is a notable potential for afforestation gains of carbon sequestration in marginally productive agricultural lands of the United States. Our conservative national projection of $0.3 \mathrm{Pg} \mathrm{C}$ potentially 


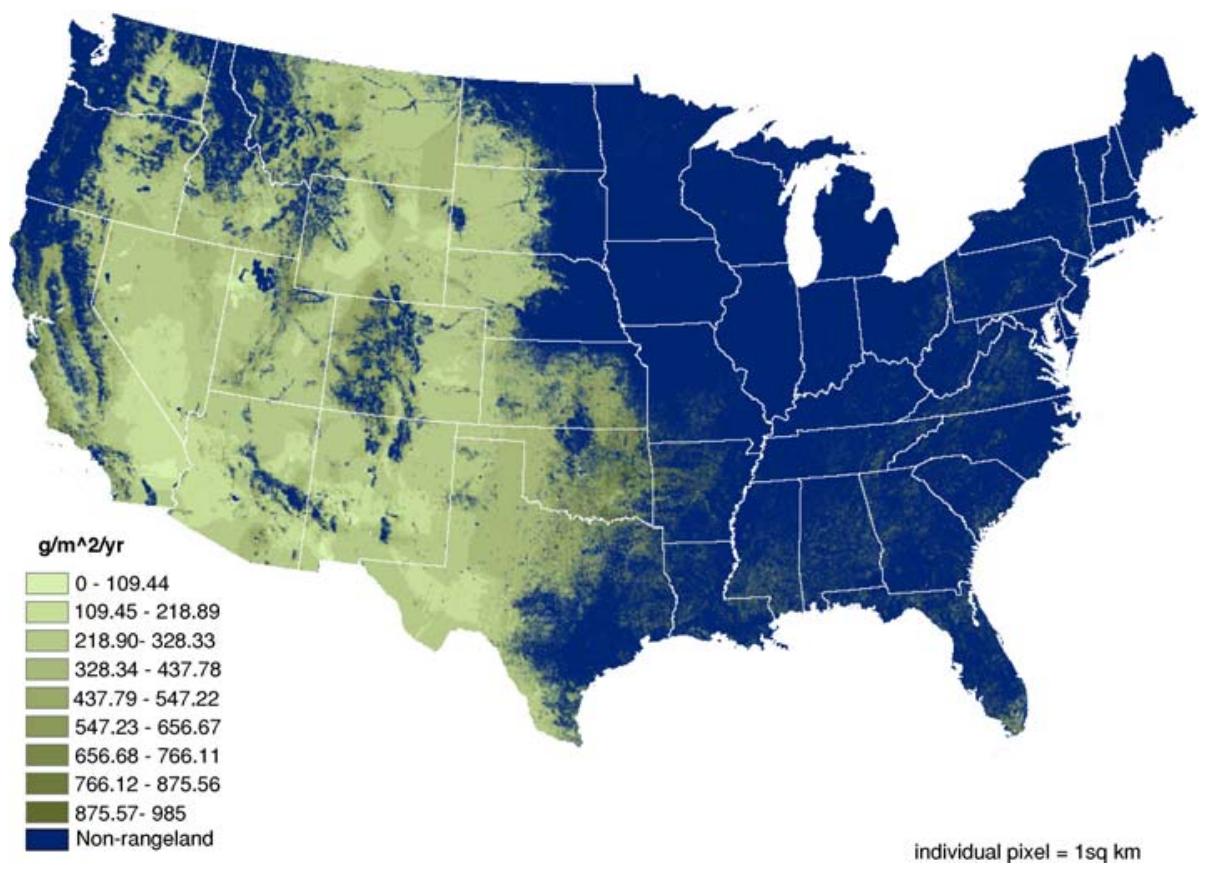

Fig. 2 Potential afforestation carbon gains in relatively low-production rangelands mapped to show predictedngross carbon sink flux per year at $1-\mathrm{km}$ resolution. Corrections for probable NPP loss over time due to decomposition, disturbance and aging in predicted forest stands are not included.

sequestered each year in crop or rangeland areas could offset nearly one-fifth of annual fossil fuel emission of carbon in the United States (EIA 2003b). Our projection for afforestation gains of carbon also exceeds recent estimates of the annual sink for atmospheric $\mathrm{CO}_{2}$ in currently forested areas of the U.S at around 0.15 Pg C (Birdsey and Heath 1995; Houghton et al. 1999; Myneni et al. 2001; Pacala et al. 2001). Moreover, newly planted forests will likely sequester carbon at faster rates overall than most currently forested area of the country, which would provide a strong carbon sink potential over next few decades to offset any slowdowns in regowth forest sinks resulting from agricultural abandonment 50-100 years ago (Houghton et al. 1999).

Satellite observations of land cover and green plant density from the MODIS sensor permit differentiation of potential forest growing areas at a spatial resolution of $1-\mathrm{km}$, with higher resolution soon to come. Statewide and some countywide assessments should be markedly enhanced at this level of biogeographic detail in new forest carbon fluxes. The effects of features such as steep mountain topography, coastal to inland climate gradients, and major land management units can be captured at these improved resolution images for continental carbon fluxes (Running et al. 2004). The MODIS-based classification of land cover has already been shown to provide more spatial detail, particularly in forested areas, than previous satellite mapping products based on AVHRR data (Loveland et al. 2000), owing mainly to the improved spectral and radiometric quality of MODIS data relative to AVHRR data (Friedl et al. 2002).

The sub-tropical climate zones of the southeastern U.S. are logically near the top of the list of areas with the most favorable conditions for afforestation carbon gains. At the Springer 


\section{Distance to Forested Cell}

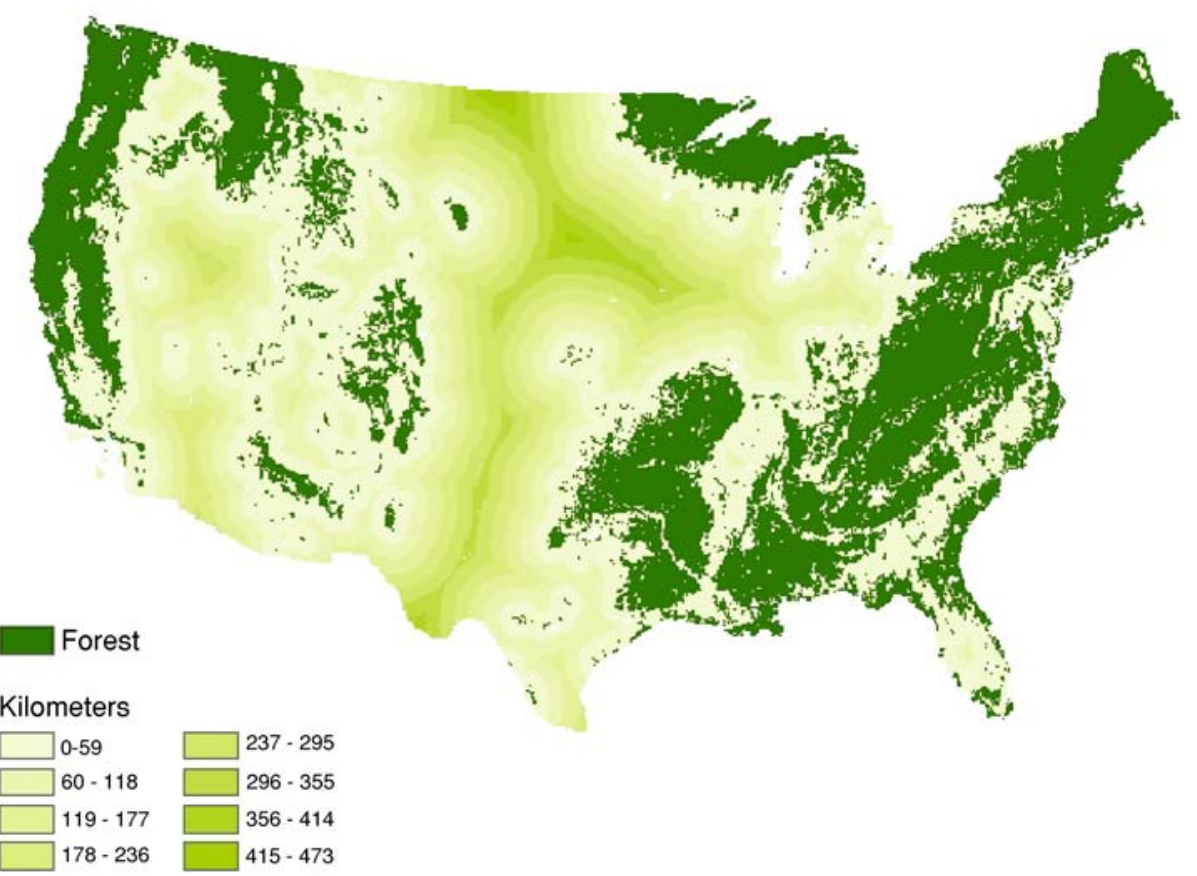

Fig. 3 Maximum distance from a forest FPAR value interpolated into the crop and rangeland areas.

national scale, our findings are generally consistent with those of Valentini et al. (2000), who presented data on net ecosystem carbon exchange in 15 European forests and demonstrated that the more southerly, warmer forests annually sequester far more carbon than the more northerly, cooler forests. Nevertheless, our model results suggest that there are relatively large areas of cropland as far north as South Dakota, Minnesota, and Wisconsin where potential afforestation gains of carbon should not be underrated.

Conservation management of forests is not a new concept to recapture industrial carbon emissions to the atmosphere. Retention of current biomass pools in forests remains essential through protection of forest reserves, alteration of harvesting regimes, and sound ecological management of disturbances such as fire and pest outbreaks. Several pressing issues now arise for new efforts to realize large additional gains in terrestrial carbon sequestration (Alig et al. 1997). What factors make large-scale afforestation efforts feasible, both ecologically and economically? What management investments are necessary to grow trees on today's marginal agricultural lands? What are the proper incentives to offer owners of these marginal lands for initiation of extensive afforestation projects?

Lewandrowski et al. (2004) addressed many of these questions and have remarked that afforestation incentives will not be strong in the Southern Plains, Northern Plains, or the Mountain regions of the U, S, because natural conditions do not favor forest growth throughout much of these regions. Establishing forests in these regions would require relatively costly human interventions (e.g., supplemental irrigation and fire-suppression activities), compared with other regions in the southern and midwestern United States. These authors point out that different sequestration activities become economically feasible at different carbon prices. 


\section{Annual EET Deficit}

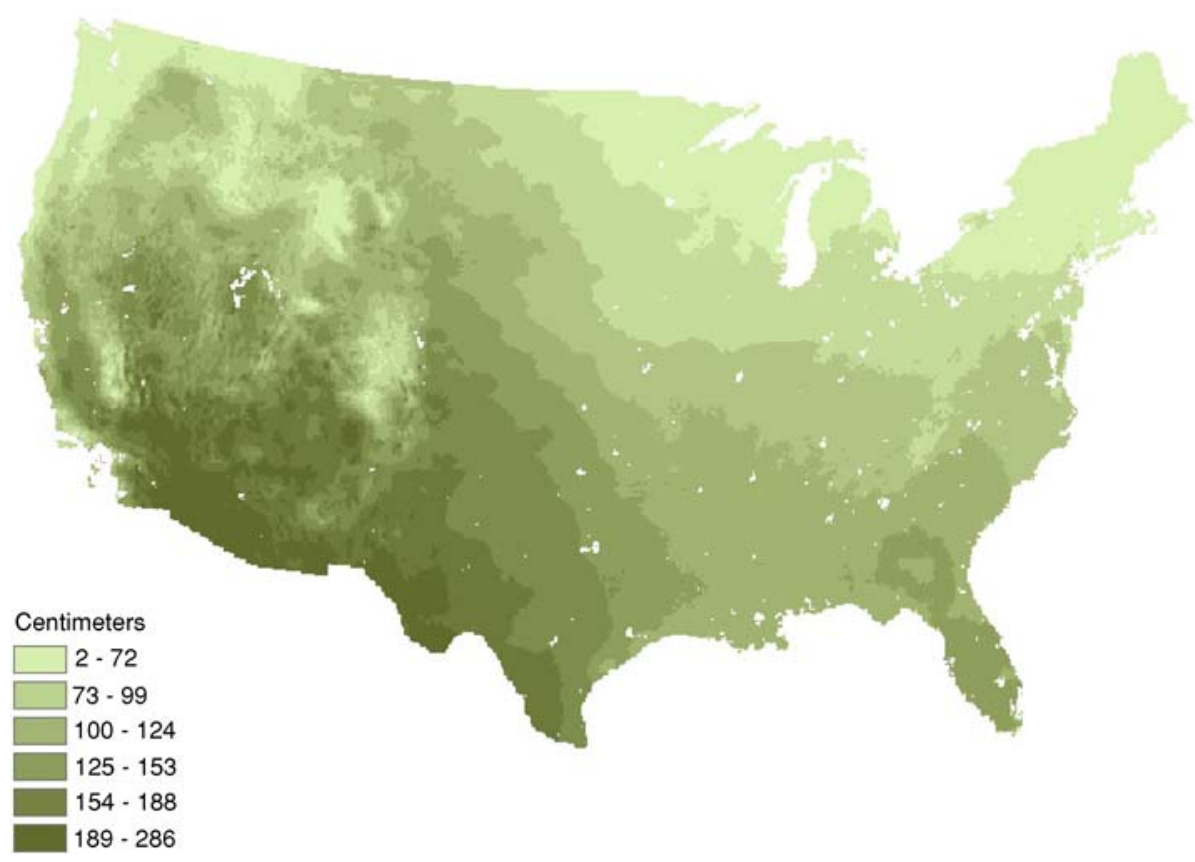

Fig. 4 The ratio of CASA's predicted annual EET to PET (i.e., estimated versus potential evapotranspiration), as an index of water demands of newly planted trees.

Their models predicted that farmers would adopt cropland management (primarily conservation tillage) at the lowest carbon price, $\$ 10$ per metric ton permanently sequestered carbon, and would convert land to forest as the price rose to $\$ 25$ and beyond. Farmers in most regions of the U.S. would not convert cropland to grassland up through a $\$ 125$ carbon price (in the absence of other incentives, such as Conservation Reserve Program payments), in part because conversion to afforestation was more profitable with its higher sequestration rate per acre.

In conclusion, results from our satellite-assisted forest modeling studies imply that, until economically affordable technologies for carbon sequestration in permanent stocks other than terrestrial ecosystems become available, the considerable potential for afforestation in the U.S. to remove $\mathrm{CO}_{2}$ from the atmosphere should turn greater attention to these issues of ecosystem carbon management and its basic incentives.

Acknowledgements This work was supported by grants from NASA program in Earth Science Applications and the Earth Observing System (EOS) Interdisciplinary Science Program.

\section{References}

Alig R, Adams D, Mccarl B, Callaway JM, Winnett S (1997) Assessing effects of mitigation strategies for global climate change with an inter-temporal model of the U.S. forest and agriculture sectors. Environ Resour Econ 9:259-274 
Birdsey RA, Heath LS (1995) Productivity of America's forest and climatic change. In: Joyce LA (ed) U.S. Department of Agriculture Forest Service, Rocky Mountain Forest and Range Experiment Station, Fort Collins, CO, General Technical Report RM-GTR 271, pp 56-70

Brown S, Sathaye J, Cannell M, Kauppi P (1996) Management of forests for mitigation of greenhouse gas emissions. In: Watson RT, Zinyowera MC, Moss RH (eds) Climate change 1995: impacts, adaptations and mitigation of climate change: scientific-technical analyses. Contribution of Working Group II to the Second Assessment Report of the Intergovernmental Panel on Climate Change. Cambridge University Press, Cambridge and New York, Chapter 24

Dixon RK (1995) Agroforestry systems: sources or sinks of greenhouse gas? Agroforestry Syst 31:99-116

Energy Information Administration (EIA) U.S. Department of Energy (2004) The voluntary reporting of greenhouse gases program. Report \#: DOE/EIA-0608, Washington, DC, 81 pp

Energy Information Administration (EIA) U.S. Department of Energy (2003a) Method for calculating carbon sequestration by trees in urban and suburban settings. United States Department of Energy Voluntary Reporting of Greenhouse Gases Program, Washington, DC, 15 pp

Energy Information Administration (EIA) U.S. Department of Energy (2003b) Emissions of greenhouse gases in the United States 2002. Office of Integrated Analysis and Forecasting, Report number DOE/EIA-0573, Washington, DC, $126 \mathrm{pp}$

Friedl MA, McIver DK, Hodges JCF, Zhang XY, Muchoney D, Strahler AH, Woodcock CE, Gopal S, Schneider A, Cooper A, Baccini A, Gao F, Schaaf C (2002) Global land cover mapping from MODIS: algorithms and early results. Remote Sensing Environ 83:287-302

Graham PJ (2003) Potential for climate change mitigation through afforestation: an economic analysis of fossil fuel substitution and carbon sequestration benefits. Agroforestry Syst 59: 85-95

Houghton RA, Hackler JL, Lawrence KT (1999) The US carbon budget: contributions from land-use change. Science 285:574-578

Intergovenmental Panel on Climate Change (IPCC) (2000) In: Watson RT, Noble IR, Bolin B, Ravindranath NH, Verardo DJ, Dokken DJ (eds) IPCC special report on land use, land-use change and forestry. Cambridge University Press, Cambridge, UK/New York, 377 pp

Knyazikhin Y, Martonchik JV, Myneni RB, Diner DJ, Running SW (1998) Synergistic algorithm for estimating vegetation canopy leaf area index and fraction of absorbed photosynthetically active radiation from MODIS and MISR data. J Geophys Res 103:32257-32276

Lewandrowski J, Peters M, Jones C, House R, Sperow M, Eve M, Paustian K (2004) Economics of sequestering carbon in the U.S. agricultural sector, economic research service. U.S. Department of Agriculture, Technical Bulletin No. (TB1909), 69 pp

Loveland TR, Reed BC, Brown JF, Ohlen DO, Zhu Z, Yang L, Merchant JW (2000) Development of a global land cover characteristics database and IGBP DISCover from $1 \mathrm{~km}$ AVHRR data. Int J Remote Sensing 21:1303-1365

Marland G, Fruit K, Sedjo R (2001) Accounting for sequestered carbon: the question of permanence. Environ Sci Policy 4:259-268

Marland G, Schlamadinger B (1997) Forests for carbon sequestration or fossil fuel substitution? A sensitivity analysis. Biomass Bioenergy 13:389-397

Myneni RB, Dong J, Tucker CJ, Kaufmann RK, Kauppi PE, Liski J, Zhou L, Alexeye1 V, Hughes MK (2000) A large carbon sink in the woody biomass of northern forests. PNAS 98:14784-14789

Nilsson S, Schopfhauser W (1995) The carbon-sequestration potential of a global afforestation programme. Climatic Change 30:267-293

Pacala SW, Hurtt GC, Baker D, Peylin P, Houghton RA, Birdsey RA, Heath L, Sundquist ET, Stallard RF, Ciais P, Moorcroft P, Caspersen JP, Shevliakova E, Moore B, Kohlmaier G, Holland E, Gloor M, Harmon ME, Fan S-M, Sarmiento JL, Goodale CL, Schimel D, Field CB (2001) Consistent land- and atmosphere-based U.S. carbon sink estimates. Science 292:2316-1320

Parton WJ, Schimel DS, Cole CV, Ojima DS (1987) Analysis of factors controlling soil organic matter levels in Great Plains grasslands. Soil Sci Soc Am J 51:1173-1179

Pew Center on Global Climate Change (2004) Climate change activities in the United States. Arlington, VA, $56 \mathrm{pp}$

Plantinga AJ, Mauldin T, Miller DJ (1999) An econometric analysis of the costs of sequestering carbon in forests. Am J Agric Econ 81:812-824

Potter CS (1999) Terrestrial biomass and the effects of deforestation on the global carbon cycle. BioScience 49:769-778

Potter CS, Randerson JT, Field CB, Matson PA, Vitousek PM, Mooney HA, Klooster SA (1993) Terrestrial ecosystem production: a process model based on global satellite and surface data. Global Biogeochemical Cycles 7(4):811-841 
Potter C, Klooster S, Myneni R, Genovese V, Tan P, Kumar V (2003) Continental scale comparisons of terrestrial carbon sinks estimated from satellite data and ecosystem modeling 1982-98. Global Planetary Change 39:201-213

Running SW, Nemani RR, Heinsch Faith A, Zhao M, Reeves M, Hashimoto H (2004) A continuous satellitederived measure of global terrestrial primary production. BioScience 54:547-560

Ryan MG, Hubbard RM, Pongracic S, Raison RJ, McMurtrie RE (1996) Foliage, fine-root, woody-tissue and stand respiration in Pinus radiata in relation to nitrogen status. Tree Physiol 16:333-343

Turner DP, Koerper GJ, Harmon ME, Lee JJ (1995) Carbon sequestration by forests of the United States: current status and projections to the year 2040. Tellus 47B:232-239

Valentini R, Matteucci G, Dolman AJ, Schulze E-D, Rebmann C, Moors EJ, Granier A, Gross P, Jensen NO, Pilegaard K, Lindroth A, Grelle A, Bernhofer C, Grunwald T, Aubinet M, Ceulemans R, Kowalski AS, Vesala T, Rannik U, Berbigier P, Loustau D, Gudmundsson J, Thorgeirsson H, Ibrom A, Morgenstern K, Clement R, Moncrieff J, Montagnani L, Minerbi S, Jarvis PG 2000. Respiration as the main determinant of carbon balance in European forests. Nature 404:861-865

VEMAP Participants, (2000) The VEMAP Phase I database: an integrated input dataset for ecosystem and vegetation modeling for the conterminous United States. CDROM and World Wide Web (URL: http://www.cgd.ucar.edu/vemap/) 